\title{
PENGARUH PEMBELAJARAN INKUIRI TERBIMBING TERHADAP PEMAHAMAN LARUTAN PENYANGGA DAN KETERAMPILAN PROSES SAINS PESERTA DIDIK
}

\author{
Ferdina D. Sulistianingrum ${ }^{\mathrm{a}}$, Sutrisno ${ }^{\mathrm{b}}$, Muhammad Su'aidy $^{\mathrm{c} 1}$ \\ a,b,c Jurusan Kimia FMIPA Universitas Negeri Malang
}

\begin{abstract}
Abstrak - Inkuiri terbimbing merupakan pembelajaran inkuiri yang melibatkan peserta didik dalam mengumpulkan dan mengolah data, memahami makna kesimpulan, dan membuat penjelasan. Penelitian ini bertujuan untuk (1) mengetahui keterlaksanaan proses pembelajaran inkuiri terbimbing, (2) mendeskripsikan keterampilan proses sains peserta didik melalui penerapan pembelajaran inkuiri terbimbing, dan (3) mengetahui pengaruh penerapan pembelajaran inkuiri terbimbing terhadap hasil belajar kognitif peserta didik. Penelitian ini menerapkan Posttest-only Control Group Quasy Experimental Design. Subjek penelitian ini adalah peserta didik kelas XI MIA 1 dan XI MIA 2 di SMA Negeri 2 Batu. Kelas XI MIA 1 berlaku sebagai kelas kontrol yang menggunakan pembelajaran ekspositori dan kelas XI MIA 2 berlaku sebagai kelas eksperimen yang menggunakan pembelajaran inkuiri terbimbing. Instrumen penelitian ini adalah instrumen perlakuan dan instrumen pengukuran. Data dianalisis menggunakan statistik deskriptif dan korelasional. Hasil penelitian menunjukkan bahwa keterlaksanaan pembelajaran larutan penyangga yang menerapkan pembelajaran inkuiri terbimbing termasuk dalam kategori sangat baik (rerata keterlaksanaan $=95,35 \%$ ). Keterampilan proses sains peserta didik yang menerapkan pembelajaran inkuiri terbimbing menunjukkan kategori sangat baik (94,70\%) dengan rincian (1) keterampilan memprediksi 87,92\%, (2) keterampilan mengobservasi 99,17\%, (3) keterampilan mengklasifikasikan 93,75\%, (4) keterampilan mengukur 95,42\%, (5) keterampilan menganalisis 94,00\%, (6) keterampilan mengkomunikasikan 95,00\%, dan (7) keterampilan menyimpulkan 97,67\%. Skor rata-rata hasil belajar kognitif larutan penyangga kelas eksperimen adalah 75,20 yang lebih tinggi dari pada kelas kontrol yang skor rata-ratanya adalah 69,13.
\end{abstract}

Kata kunci: Pembelajaran inkuiri terbimbing, Keterampilan proses sains, Larutan penyangga

Abstract - Guided inquiry is one of the learning that requires students to collect and process
data, understand the meaning of conclusion, and make an explanation. The aims of this research
are (1) to determine the feasibility of guided inquiry learning implementation; (2) to describe
science process skills that students have with applying guided inquiry learning, and (3) to
know influence of applying guided inquiry learning towards to cognitive's students learning
outcomes. This research applied a quasi-experimental with posttest-only control group
design. The subjects of this research are students in class of Science 1 and Science 2 grade XI at

${ }^{1}$ Corresponding authors: Muhammad Su'aidy, Program Studi Pendidikan Kimia, Universitas Negeri Malang, Malang 65145, Indonesia. Email: m.suaidy.fmipa@um.ac.id

ISSN: 2528-6536 (cetak)/ISSN: 2579-5945 (online)

@2017 J-PEK 
SMA Negeri 2 Batu. The instruments of this research are treatment instrument and measurement instrument. The data were analyzed by descriptive analysis and correlational. The science process skills of students who apply guided inquiry learning show very good (94.70\%) with details (1) predicting skills $87.92 \%$, (2) observing skills $99.17 \%$, (3) classify skills $93.75 \%$, (4) measure skills $95.42 \%$, (5) analyze skills $94.00 \%$, (6) communicate skills $95.00 \%$, and (7) conclude skills 97,67\%. The average score of cognitive learning outcomes on buffer solution of the experimental class was 75.20 higher than the control class whose mean score was 69.13 .

Keywords: Guided inquiry learning, Science process skills, Buffer solution

\section{PENDAHULUAN}

Ilmu kimia merupakan ilmu yang mengkaji fakta yang diperoleh secara empirik melalui observasi yang menghasilkan suatu konsep. Seiring dengan perkembangan ilmu pengetahuan alam termasuk ilmu kimia, maka diperlukan generasi muda yang kompeten, khususnya dalam dunia pendidikan. Proses belajar mengajar yang menekankan pada pembangunan konsep secara mandiri dapat menjadi salah satu cara untuk mencapai tujuan tersebut. Selain itu, menjadikan peserta didik layaknya kimiawan dalam proses pembelajaran kimia akan lebih efektif dalam membangun konsep. Implementasi pembelajaran yang demikian dapat menempatkan peserta didik sebagai subjek belajar yang akan mencari kebenaran ilmiah melalui serangkaian langkah-langkah yang sistematis. Hasil yang diharapkan adalah peserta didik mampu mengembangkan proses berinkuiri dan pembentukan sikap. Selaras dengan hal tersebut, dalam pembelajaran sains, peserta didik dituntut memiliki kemampuan dasar bekerja ilmiah (Rustaman, 2005). Salah satu dari kemampuan dasar kerja ilmiah atau scientific inquiry adalah dimilikinya keterampilan proses sains pada diri peserta didik. Adanya keterampilan proses sains dapat mengembangkan keterampilan berpikir dengan baik (Ismail dan Jusoh, 2001). Keterampilan proses sains juga dapat meningkatkan kreativitas sains dan capaian hasil belajar peserta didik (Aktamis dan Ergin, 2008).

Pembelajaran dengan tujuan meningkatkan keterampilan proses sains dapat memberikan kesempatan kepada peserta didik untuk terlibat langsung dalam kerja ilmiah, sehingga peserta didik memiliki pengalaman dalam membangun konsep pengetahuannya. Pembelajaran inkuiri merupakan salah satu pembelajaran yang menuntut peserta didik untuk aktif dalam kegiatan ilmiah. Berdasarkan kharakteristiknya, terdapat keselarasan antara ilmu kimia dengan pembelajaran inkuiri. Pembelajaran inkuiri yang cocok diterapkan pada peserta didik di SMA adalah pembelajaran inkuiri terbimbing. Hal ini dikarenakan peserta didik pada tingkat SMA masih belum mampu untuk melakukan inkuiri sepenuhnya, sehingga dalam berpikir kritis dan mendesain eksperimen masih perlu adanya bimbingan dari guru.

Berdasarkan hasil wawancara yang dilakukan penulis dengan salah satu guru kimia kelas XI SMA Negeri 2 Batu, diperoleh informasi bahwa keterampilan proses sains peserta didik kelas XI dalam mempelajari kimia masih sangat kurang. Hal ini juga didukung oleh hasil observasi terhadap keaktifan, keantusiasan, dan keterampilan peserta didik yang masih kurang, serta peserta didik cenderung sebagai penghafal rumus. Dilihat dari capaian hasil ulangan harian pada topik asam basa, sekitar $40 \%$ peserta didik kelas XI belum mencapai nilai KKM. Oleh karena itu, untuk meningkatkan keaktifan, 
pemahaman, dan keterampilan proses sains peserta didik kelas XI SMA Negeri 2 Batu perlu dilakukan pembelajaran inkuiri terbimbing.

Beberapa penelitian telah dilakukan untuk mengetahui keefektifan dari pembelajaran inkuiri terbimbing, di antaranya penelitian yang dilakukan oleh Ifeoma \& Oge (2013) yang menunjukkan bahwa pembelajaran inkuiri terbimbing dapat meningkatkan prestasi belajar dan partisipasi peserta didik dibanding pembelajaran konvensional. Penelitian Wahyuningsih, Hantoro, dan Indana (2011) menunjukkan bahwa pembelajaran inkuiri dapat meningkatkan kinerja ilmiah peserta didik. Penelitian Matthew dan Igharo (2013) menunjukkan bahwa dalam berlogika, hasil belajar peserta didik yang dibelajarkan dengan pembelajaran inkuiri terbimbing lebih baik daripada peserta didik yang dibelajarkan secara pembelajaran konvensional. Kemudian, penelitian yang dilakukan Maikristina (2013) yang menunjukkan bahwa hasil belajar dan keterampilan proses sains peserta didik yang dibelajarkan dengan pembelajaran inkuiri terbimbing lebih baik daripada peserta didik yang dibelajarkan dengan pembelajaran problem solving. Namun penelitian tersebut dilakukan pada tempat yang berbeda-beda. Berdasarkan permasalahan yang telah dipaparkan sebelumnya, maka penulis bermaksud untuk melakukan penerapan pembelajaran inkuiri terbimbing di kelas XI SMA Negeri 2 Batu.

Larutan penyangga merupakan salah satu kajian ilmu kimia yang ada di kelas XI. Pokok bahasan dalam materi ini lebih mengarah pada pembangunan konsep yang dapat dilakukan dengan melakukan kerja ilmiah seperti eksperimen atau analisis data, serta perhitungan kimia. Pokok bahasan yang demikian menunjukkan adanya keselarasan dengan kharakter pembelajaran inkuiri terbimbing. Berdasarkan uraian di atas, maka penelitian ini akan mengkaji tentang keterlaksanaan proses pembelajaran inkuiri terbimbing, keterampilan proses sains peserta didik yang dibelajarkan dengan pembelajaran inkuiri terbimbing, dan pengaruh penerapan pembelajaran inkuiri terbimbing terhadap hasil belajar kognitif peserta didik.

\section{METODE}

Rancangan penelitian yang digunakan pada penelitian ini adalah rancangan eksperimen semu (Quasy Experimental) dengan posttest-only control group design, seperti yang tertera pada Tabel 1.

Tabel 1. Rancangan Penelitian Post-test Only Group Design

\begin{tabular}{lcc}
\hline Subjek & Perlakuan & Post-test \\
\hline $\mathrm{E}$ & $\mathrm{X} 1$ & $\mathrm{O} 1$ \\
$\mathrm{~K}$ & $\mathrm{X} 2$ & $\mathrm{O} 2$ \\
\hline
\end{tabular}

(Sugiyono, 2013: 112)

Keterangan:

$\mathrm{E} \quad=$ Kelompok eksperimen

$\mathrm{K} \quad=$ Kelompok kontrol

$\mathrm{X} 1=$ Perlakuan dengan menggunakan pembelajaran inkuiri terbimbing

$\mathrm{X} 2=$ Perlakuan dengan menggunakan pembelajaran ekspositori

O1 = Nilai post-test peserta didik yang dibelajarkan dengan pembelajaran inkuiri terbimbing

$\mathrm{O} 2=$ Nilai post-test peserta didik yang dibelajarkan dengan pembelajaran ekspositori 
Subjek penelitian yang digunakan adalah peserta didik kelas XI MIA 1 dan XI MIA 2 SMA Negeri 2 Batu. Kelas XI MIA 1 digunakan sebagai kelas kontrol yang dibelajarkan dengan pembelajaran ekspositori dan kelas XI MIA 2 digunakan sebagai kelas eksperimen yang dibelajarkan dengan pembelajaran inkuiri terbimbing. Penelitian dilaksanakan di SMA Negeri 2 Batu. Waktu penelitian dilaksanakan pada tanggal 27 Februari sampai dengan 10 April 2015 pada semester genap tahun ajaran 2014/2015.

Variabel bebas pada penelitian ini adalah pembelajaran yang digunakan. Variabel terikat yang digunakan adalah hasil belajar kognitif. Variabel kontrol yang digunakan adalah alokasi waktu dan materi pembelajaran larutan penyangga. Analisis deskriptif digunakan untuk mendeskripsikan keterlaksanaan proses pembelajaran dan keterampilan proses sains. Analisis statistik digunakan untuk menganalisis perbandingan hasil belajar kognitif.

\section{Keterlaksanaan Proses Pembelajaran}

Data keterlaksanaan proses pembelajaran yang telah diperoleh dari hasil pengamatan, dianalisis dari segi pelaksanaan kegiatan selama pembelajaran. Presentase keterlaksanaan proses pembelajaran dianalisis dengan teknik perhitungan menggunakan rumus:

$$
\mathrm{P}_{\mathrm{kp}}=\frac{\mathrm{N}_{\mathrm{t}}}{\mathrm{N}_{\mathrm{i}}} \mathrm{X} 100 \%
$$

Keterangan:

Pkp = Presentase keterlaksaan pembelajaran

$\mathrm{Nt} \quad=$ Jumlah kegiatan pembelajaran yang terlaksana

$\mathrm{Ni} \quad=$ Jumlah ideal kegiatan pembelajaran

Kriteria kualitas keterlaksanaan pembelajaran disajikan pada Tabel 2.

Tabel 2. Kriteria Kualitas Keterlaksaan Proses Pembelajaran

\begin{tabular}{cc}
\hline Nilai $\mathrm{P}_{\mathrm{Kp}}$ & Kriteria \\
\hline $0 \%-25 \%$ & Sangat jelek \\
$25,1 \%-50 \%$ & Jelek \\
$50,1 \%-75 \%$ & Baik \\
$75,1 \%-100 \%$ & Sangat baik \\
\hline
\end{tabular}

(Kartini dalam Aprilia, 2012:41)

\section{Hasil Belajar Kognitif}

Analisis hasil belajar kognitif diukur dengan menggunakan nilai hasil ulangan harian selesai dilaksanakan. Pengukuran dilakukan dengan menggunakan soal tes pilihan ganda berjumlah 21 soal dengan 5 alternatif jawaban.

Analisis statistik yang digunakan untuk menguji hipotesis adalah dengan uji t satu pihak dengan rumus:

$$
\mathrm{t}=\frac{\overline{\mathrm{x}}-\mu_{0}}{\frac{s}{\sqrt{n}}}
$$

(Sugiyono, 2013: 250) 
Keterangan:

$\frac{\mathrm{t}}{\mathrm{X}} \quad=$ nilai $\mathrm{t}$ yang dihitung

$\bar{X} \quad=$ nilai rata-rata peserta didik yang dibelajarkan dengan pembelajaran inkuiri terbimbing

$\mu 0=$ nilai yang dihipotesiskan

$\mathrm{s} \quad=$ simpangan baku hasil belajar kognitif peserta didik

$\mathrm{n} \quad=$ jumlah peserta didik yang dibelajarkan dengan pembelajaran inkuiri terbimbing

Kriteria uji-t dapat dituliskan sebagai berikut.

- Apabila nilai $t_{\text {hitung }}<\mathrm{t}_{\text {tabel }}$ maka $\mathrm{H} 0$ diterima dan $\mathrm{H}_{\mathrm{a}}$ ditolak

- Apabila nilai $t_{\text {hitung }}>\mathrm{t}_{\text {tabel }}$ maka $\mathrm{H} 0$ ditolak dan $\mathrm{H}_{\mathrm{a}}$ diterima.

Sebelum dilakukan uji hipotesis, data hasil belajar kognitif peserta didik harus memenuhi uji prasyarat terlebih dahulu, yaitu meliputi uji normalitas dan homogenitas.

\section{Keterampilan Proses Sains}

Analisis pencapaian keterampilan proses sains menggunakan lembar observasi dengan penilaian menggunakan skala Likert 1-4. Langkah-langkah yang dilakukan dalam analisis keterampilan proses sains peserta didik yang dibelajarkan dengan pembelajaran inkuiri terbimbing adalah sebagai berikut:

1) Memberi skor pada masing-masing keterampilan berdasarkan rubrik penilaian.

2) Mengubah skor ke dalam persentase berdasarkan rumus:

$$
\text { Nilai }=\frac{\sum \text { skor mentah }}{\sum \text { skor maksimal }} \times 100 \%
$$

3) Menghitung persentase tiap sub keterampilan dan menentukan kategori persentase tersebut berdasarkan skala kategori pada Tabel 3.

Tabel 3. Kriteria Persentase Keterampilan Proses Sains

\begin{tabular}{cc}
\hline Nilai persentase $(\%)$ & Kategori \\
\hline $81-100$ & Sangat baik \\
$61-80$ & Baik \\
$41-60$ & Cukup \\
$21-40$ & Kurang \\
$<20$ & Sangat kurang \\
\hline
\end{tabular}

4) Menghitung sebaran kriteria keterampilan proses sains

$$
\text { sebaran }=\frac{\sum \text { siswa tiap kriteria }}{\sum \text { siswa total }} \times 100 \%
$$




\section{HASIL DAN PEMBAHASAN}

\section{HASIL}

\section{Keterlaksanaan Proses Pembelajaran}

Data keterlaksanaan proses pembelajaran inkuiri terbimbing diperoleh pada saat pembelajaran berlangsung melalui pengamatan yang dilakukan oleh observer. Data keterlaksanaan pembelajaran inkuiri terbimbing dapat dilihat pada Tabel 4.

Tabel 4. Data Keterlaksanaan Proses Pembelajaran Inkuiri Terbimbing Topik Larutan Penyangga

\begin{tabular}{lcccc}
\hline \multirow{2}{*}{ RPP } & \multicolumn{2}{c}{ Penilaian } & \multicolumn{2}{c}{ Persentase Proses Pembelajaran } \\
\cline { 2 - 5 } & Observer 1 & Observer 2 & Terlaksana & Tidak terlaksana \\
\hline I & $95 \%$ & $95 \%$ & $95 \%$ & $5 \%$ \\
II & $89,47 \%$ & $89,47 \%$ & $89,47 \%$ & $10,53 \%$ \\
III & $97 \%$ & $97 \%$ & $97 \%$ & $3 \%$ \\
IV & $100 \%$ & $100 \%$ & $100 \%$ & $0 \%$ \\
\hline \multicolumn{2}{r}{} & Rata-rata secara keseluruhan & $95,35 \%$ & $4,65 \%$ \\
\hline
\end{tabular}

Tabel 4 menunjukkan bahwa rata-rata persentase keterlaksanaan pembelajaran inkuiri terbimbing sebesar 95,35\%. Dengan demikian dapat disimpulkan bahwa proses pembelajaran dengan pembelajaran inkuiri terbimbing telah terlaksana dengan sangat baik.

\section{Hasil Belajar Kognitif}

Hasil belajar kognitif peserta didik menunjukkan kemampuan peserta didik kelas eksperimen dan kontrol setelah diberikan perlakuan. Data hasil belajar kognitif diperoleh dari hasil tes yang dilakukan setelah semua proses pembelajaran dilaksanakan. Ringkasan data tertera pada Tabel 5.

Tabel 5. Ringkasan Data Hasil Belajar Kognitif Peserta didik Kelas Eksperimen dan Kelas Kontrol

\begin{tabular}{lcc}
\hline \multicolumn{1}{c}{ Uraian } & \multicolumn{2}{c}{ Kelas } \\
\cline { 2 - 3 } & Kontrol & Eksperimen \\
\hline Jumlah peserta didik & 30 peserta didik & 30 peserta didik \\
Rata-rata & 69,13 & 75,20 \\
Median & 69,00 & 76,00 \\
Simpangan baku & 8,08 & 10,39 \\
Nilai tertinggi & 90,00 & 95,00 \\
Nilai terendah & 57,00 & 57,00 \\
\hline
\end{tabular}

Berdasarkan hasil analisis menunjukkan bahwa rata-rata hasil belajar kognitif peserta didik yang dibelajarkan dengan pembelajaran inkuiri terbimbing lebih tinggi dari rata-rata hasil belajar kognitif peserta didik yang dibelajarkan dengan pembelajaran ekspositori.

\section{Keterampilan Proses Sains}

Data pencapaian keterampilan proses sains peserta didik dilihat berdasarkan lembar observasi selama proses pembelajaran berlangsung. Ringkasan pencapaian keterampilan proses sains tertera pada Tabel 6. 
Tabel 6. Ringkasan Pencapaian Keterampilan Proses Sains Peserta didik

\begin{tabular}{lcc}
\hline \multicolumn{1}{c}{ Keterampilan Proses Sains } & $\begin{array}{c}\text { Persentase Rata-rata Pencapaian } \\
\text { Proses Sains }\end{array}$ & Kriteria \\
\hline Memprediksi & $87,92 \%$ & Sangat baik \\
Mengobservasi & $99,17 \%$ & Sangat baik \\
Mengklasifikasikan & $93,75 \%$ & Sangat baik \\
Mengukur & $95,42 \%$ & Sangat baik \\
Menganalisis & $94,00 \%$ & Sangat baik \\
Mengkomunikasikan & $95,00 \%$ & Sangat baik \\
Menyimpulkan & $97,67 \%$ & Sangat baik \\
\hline \multicolumn{1}{c}{ Rata-rata pencapaian } & $94,70 \%$ & Sangat baik \\
\hline
\end{tabular}

Berdasarkan Tabel 6 pencapaian keterampilan proses sains peserta didik yang dibelajarkan dengan pembelajaran inkuiri terbimbing termasuk dalam kriteria sangat baik.

\section{PEMBAHASAN}

Tabel 4 menunjukkan bahwa keterlaksanaan proses pembelajaran inkuiri terbimbing dari pertemuan pertama sampai pada pertemuan keempat telah terlaksana dengan sangat baik. Hal tersebut dapat dibuktikan dengan nilai rata - rata persentase keterlaksanaan pembelajaran dari pertemuan pertama sampai keempat sebesar 95,35\%. Persentase keterlaksanaan RPP tersebut menunjukkan ketercapaian pelaksanaan pembelajaran yang dilakukan pada setiap pertemuan berdasarkan pengamatan observer. Persentase keterlaksanaan rencana pelaksanaan pembelajaran (RPP) belum terlaksana secara maksimal (persentase keterlaksanaan belum mencapai 100\%) hal ini dikarenakan adanya langkah- langkah pembelajaran yang tidak terlaksana disebabkan waktu yang disediakan tidak mencukupi.

Tabel 5 menunjukkan bahwa rata-rata hasil belajar kognitif peserta didik yang dibelajarkan dengan pembelajaran inkuiri terbimbing (rerata $=75,20$ ) lebih tinggi dari rata-rata hasil belajar kognitif peserta didik yang dibelajarkan dengan pembelajaran ekspositori (rerata $=69,13$ ). Hasil yang diperoleh menunjukkan bahwa pada pokok bahasan larutan penyangga, pembelajaran inkuiri terbimbing lebih cocok digunakan daripada pembelajaran ekspositori. Tingginya rata-rata nilai peserta didik yang dibelajarkan dengan pembelajaran inkuiri terbimbing dapat dipengaruhi oleh beberapa faktor, yaitu: (1) di dalam pembelajaran dengan inkuiri terbimbing peserta didik diberikan kebebasan untuk belajar sesuai dengan gaya belajarnya, (2) adanya pemberian masalah mendorong rasa ingin tahu peserta didik, sehingga terpacu untuk memecahkan masalah, (3) keterarahan proses pembelajaran berlangsung sistematis membuat pembelajaran lebih bermakna, (4) adanya antusias peserta didik ketika proses pembelajaran berlangsung dikarenakan komunikasi berlangsung dua arah yaitu antara peserta didik dengan guru dan juga sebaliknya, hal ini terlihat ketika tahap evaluasi hipotesis peserta didik berantusias dalam mengkomunikasikan hasil analisisnya. Apabila dibandingkan dengan pembelajaran inkuiri terbimbing, pembelajaran ekspositori cenderung membuat peserta didik bosan dikarenakan peran guru yang cenderung dominan.

Hasil penelitian ini juga didukung oleh penelitian sebelumnya yang menunjukkan hasil yang selaras. Penelitian Ifeoma dan Oge (2013) yang menunjukkan bahwa 
pembelajaran inkuiri dapat meningkatkan prestasi belajar dan partisipasi peserta didik dibanding pembelajaran konvensional, kemudian penelitian yang dilakukan oleh Matthew dan Igharo (2013) yang menunjukkan dalam berlogika hasil belajar peserta didik yang dibelajarkan dengan pembelajaran inkuiri terbimbing lebih baik daripada peserta didik yang dibelajarkan dengan pembelajaran konvensional.

Tabel 6 menunjukkan bahwa persentase ketercapaian keterampilan proses sains dalam mempelajari pokok bahasan larutan penyangga dengan pembelajaran inkuiri terbimbing. Pencapaian tertinggi terdapat pada keterampilan mengobservasi yaitu 99,17\%. Hal ini dikarenakan peserta didik telah mendapat pengalaman bagaimana cara mengobservasi ketika melakukan praktikum dalam mata pelajaran IPA pada tingkat pendidikan sebelumnya, sehingga peserta didik sudah terampil dalam mengobservasi suatu peristiwa yang ditemukan dalam pengamatan. Menurut Dimyati dan Mudjiono (2006: 142), informasi yang diperoleh dari kegiatan pengamatan dapat menuntut sesorang untuk meneliti lebih lanjut. Keterampilan mengobservasi merupakan keterampilan paling dasar dalam memproses dan memperoleh ilmu pengetahuan serta keterampilan proses lainnya.

Pencapaian keterampilan proses sains terendah terletak pada keterampilan memprediksi yaitu $87,92 \%$. Rendahnya pencapaian keterampilan memprediksi dikarenakan peserta didik masih belum terbiasa untuk membuat hipotesis sehingga peserta didik masih mengalami kesulitan dalam berhipotesis. Pencapaian keterampilan proses sains mengukur, mengklasifikasikan, menganalisis, mengkomunikasikan, dan menyimpulkan memiliki pencapaian yang sangat baik. Secara keseluruhan persentase pencapaian keterampilan proses sains peserta didik termasuk ke dalam kriteria sangat baik, hal ini dikarenakan pembelajaran inkuiri terbimbing merupakan pembelajaran yang menekankan proses dalam membangun konsep. Hasil penelitian yang diperoleh membuktikan pendapat Gulo (2002:93) yang menyatakan bahwa pembelajaran inkuiri tidak hanya mengembangkan kemampuan intelektual tetapi seluruh potensi yang ada, termasuk mengembangkan emosional dan keterampilan. Pada hakikatnya, inkuiri merupakan suatu proses, yang dimulai dari kegiatan identifikasi masalah hingga menarik kesimpulan, sehingga secara tidak langsung memberikan dampak pula pada keterampilan memproses secara ilmiah peserta didik (Gulo, 2002:101). Hal ini juga didukung oleh penelitian yang dilakukan Wahyuningsih, Hantoro, dan Indana (2011) yang menunjukkan bahwa pembelajaran inkuiri memiliki langkah- langkah yang sejalan dengan pengembangan kinerja ilmiah peserta didik.

\section{KESIMPULAN}

Berdasarkan rumusan masalah dan hasil penelitian yang telah dilakukan, dapat disimpulkan sebagai berikut:

1. Pembelajaran larutan penyangga dengan pembelajaran inkuiri terbimbing pada kelas XI MIA 2 SMA Negeri 2 Batu berlangsung dengan kriteria sangat baik (persentase rata-rata pencapaian keterlaksanaan 95,35\%), meskipun dalam pembelajarannya terdapat beberapa langkah yang tidak terlaksana atau terlaksana dengan waktu melebihi perencanaan.

2. Pembelajaran larutan penyangga dengan pembelajaran inkuiri terbimbing mempunyai hasil belajar kognitif lebih tinggi dibandingkan dengan pembelajaran 
ekspositori. Rata-rata pencapaian hasil belajar kognitif peserta didik yang dibelajarkan dengan pembelajaran inkuiri terbimbing sebesar 75,20, sedangkan rata-rata pencapaian hasil belajar kognitif peserta didik yang dibelajarkan dengan pembelajaran ekspositori sebesar 69,13.

3. Rata-rata pencapaian keterampilan proses sains peserta didik yang dibelajarkan dengan pembelajaran inkuiri terbimbing sebesar $94,70 \%$ dan termasuk ke dalam kriteria sangat baik. Persentase rata-rata pencapaian keterampilan proses sains peserta didik yang dibelajarkan dengan pembelajaran inkuiri terbimbing secara berturut-turut adalah keterampilan memprediksi 87,92\%, keterampilan mengobservasi 99,17\%, keterampilan mengklasifikasikan 93,75\%, keterampilan mengukur $95,42 \%$, keterampilan menganalisis 94,00\%, keterampilan mengkomunikasikan $95,00 \%$, dan

keterampilan menyimpulkan $97,67 \%$.

Mengacu pada hasil penelitian yang telah dilakukan, saran peneliti yang dapat disampaikan adalah sebagai berikut:

1. Kepada peneliti lain yang ingin melanjutkan penelitian sejenis hendaknya rumusan masalah dibuat sendiri oleh peserta didik sehingga peserta didik dapat terlatih dan kreatif dalam bertanya atau mengamati sebuah fenomena.

2. Hendaknya kepada peneliti selanjutnya memastikan bagaimana kemampuan awal peserta didik tentang topik asam basa, karena merupakan pengetahuan dasar yang harus dimengerti peserta didik dalam mempelajari larutan penyangga.

3. Hendaknya kepada guru atau peneliti selanjutnya memperhatikan perhitungan alokasi waktu dengan benar, karena dalam membelajarkan kimia khususnya dengan topik larutan penyangga diperlukan waktu yang relatif banyak.

\section{DAFTAR RUJUKAN}

Aktamis, H. dan Ergin, O. 2008. The Effect of Scientific Process Skills Education on Students' Scientific Creativity, Science Attitude, and Academic Achievements. Asia-Pacific Forum on Science Learnig and Teaching, (Online), 9(4): 1-21, (http: //www.ied.edu.hk/apfslt/download/ v9_issuel_files/aktamis.pdf), diakses tanggal 23 April 2015.

Aprilia, N. 2012. Pengarub Penerapan Model Pembelajaran Learning Cycle 5 Fase pada Materi Larutan Penyangga terhadap Hasil Belajar Peserta didik Kelas XI SMA Negeri 2 Malang. Skripsi tidak diterbitkan. Malang: Fakultas Matematika dan Ilmu Pengetahuan Alam Universitas Negeri Malang.

Buck, L.B. Bretz, S.L, dan Towns, M.H. 2008. Characterizing the Level of Inquiry in the Undergraduate laboratory. Journal of College Science Teaching, (Online), (http://www.chem.purdue.edu), diakses tanggal 17 Mei 2014.

Dimyati dan Mudjiono. 2006. Belajar dan Pembelajaran. Jakarta: Rineka Cipta. Gulo, W. 2002. Strategi Belajar Mengajar. Jakarta: PT Grasindo.

Ifeoma, O.E dan Oge, E. K. 2013. Effect of Guide Inquiry Method on Secondary School Students' Perfomance in Social Studies Curriculum in Anambra State, Nigeria. British Journal of Education, Society \& Behavioural Science, (Online), 3 (3): 206-222, (www.sciencedomain.org), diakses tanggal 12 Februari 2014.

Ismail, Z.H.dan Jusoh, I. 2001. Relationship Between Science Process Skills and Logical Thinking Abilities of Malaysian Students. Journal of Science and Mathematics Education in S.E Asia, (Online), 24 (2): 67-77, (http://www.zrecsam.edu.my/R\&D Journals/YEAR2001/2001Vol24No2/67-77.pdf), diakses tanggal 23 April 2015. 
Maikristina, N. 2013. Pengaruh Penggunaan Model Pembelajaran Inkuiri Terbimbing terhadap Hasil Belajar dan Keterampilan Proses Sains Peserta didik. Kelas XI IPA SMAN 3 Malang pada Materi Hidrolisis Garam. Skripsi tidak diterbitkan. Malang: Fakultas Matematika dan Ilmu Pengetahuan Alam Universitas Negeri Malang.

Matthew, B.M. dan Igharo, O.K. 2013. A Study on The Effects of Guide Inquiry Teaching Method on Students Achievement in Logic. International Researcher, (Online), 2 (1): 135-140, (http:/ /iresearcher.org), diakses tanggal 4 Februari 2014.

Rustaman, N.Y. 2005. Perkembangan Penelitian Pembelajaran Berbasis Inkuiri dalam Pendidikan Sains. Makalah disaijkan dalam Seminar Nasional II Himpunan Ikatan Sarjana dan Pemerhati Pendidikan IPA Indonesia Bekerjasama dengan FMIPA Universitas Pendidikan Indonesia, Bandung, 22-23 Juli 2005. (Online), (http://file.upi.edu/Direktori/SPS/ PRODI.PENDIDIKAN IPA/195012311979032NURYANI_RUSTAMAN/PenPemInkuiri.pdf), diakses tanggal 1 Desember 2014.

Sanjaya, W. 2011. Strategi Pembelajaran Berorientasi Standar Proses Pendidikan. Jakarta: Kencana Prenada Media. Sugiyono. 2013. Metode Penelitian Pendidikan (Pendekatan Kuantitatif, Kualitatif, dan RひDD). Bandung: Alfabeta.

Wahyuningsih, E., Hantoro, dan Indana, S. 2011. Penerapan Pembelajaran Inkuiri Untuk Meningkatkan Kinerja Ilmiah Pada Mata Pelajaran Ilmu Pengetahuan Alam. Jurnal PTK DBE 3, (Online), khusus (1): 25-32 (http://inovasipendidikan.net), diakses tanggal 4 Februari 2014. 